\title{
Loss of heterozygosity on chromosome 10q23 and mutation of the phosphatase and tensin homolog deleted from chromosome 10 tumor suppressor gene in Korean hepatocellular carcinoma patients
}

\author{
JEI-JUN BAE ${ }^{1}$, JIN-WOO RHO ${ }^{2}$, TAE-JIN LEE ${ }^{4}$, SUNG-SU YUN ${ }^{2}$, HONG-JIN KIM ${ }^{2}$, \\ JOON-HYUK CHOI ${ }^{3}$, DAEWON JEONG ${ }^{1}$, BYEONG-CHURL JANG ${ }^{4}$ and TAE-YOON LEE ${ }^{1}$
}

Departments of ${ }^{1}$ Microbiology, ${ }^{2}$ General Surgery, and ${ }^{3}$ Pathology, College of Medicine, Yeungnam University, 317-1 Daemyung-Dong, Nam-Gu, Daegu 705-717; ${ }^{4}$ Chronic Disease Research Center and Institute for Medical Science, Keimyung University School of Medicine, Jung-Gu, Daegu 700-712, Korea

Received April 3, 2007; Accepted May 29, 2007

\begin{abstract}
Loss of heterozygosity (LOH) in the 10q23 chromosomal region was analyzed in 18 tissue samples from Korean hepatocellular carcinoma (HCC) patients. $\mathrm{LOH}$ at the phosphatase and tensin homolog deleted from chromosome 10 (PTEN) region (D10S215, AFMa086wg9 and D10S541) was found in 8 of the $18(44.4 \%)$ HCCs. LOH (20\%) and microsatellite instability $(26.7 \%)$ were also frequently found at the D10S2177 locus, which is located on the telomere side of the PTEN region. $\mathrm{LOH}$ was found in other loci, such as AFM280we 1 and D10S2281. The presence of LOH in regions other than the PTEN region on chromosome 10q23 suggested the presence of additional tumor suppressor gene(s). PTEN mutation was found in only a subset of HCCs: A single base insertion at the end of the 5'-end splice signal (AG-GUAAG $\underline{\mathbf{U} U}$ ) in intron 5 and a silent mutation in exon 6 (codon 188, CTG-Val to CTA). Our data collectively suggest that the genetic alterations of chromosome 10q23, including the PTEN gene, could be important in hepatocarcinogenesis in the Korean population.
\end{abstract}

Correspondence to: Dr Tae-Yoon Lee, Department of Microbiology, College of Medicine, Yeungnam University, 317-1 Daemyung-Dong, Nam-Gu, Daegu 705-717, Korea

E-mail: doxr7p@med.yu.ac.kr

Abbreviations: HCC, hepatocellular carcinoma; $\mathrm{LOH}$, loss of heterozygosity; PTEN, phosphatase and tensin homolog deleted from chromosome 10; PIP3, phosphatidylinositol-3,4,5-triphosphate; PI3K, phosphoinositide 3-kinase; PKB, protein kinase B; SSCP, singlestrand conformational polymorphism; PCR, polymerase chain reaction

Key words: hepatocellular carcinoma, phosphatase and tensin homolog deleted from chromosome 10, 10q23, loss of heterozygosity, alteration, mutation

\section{Introduction}

Human hepatocellular carcinoma (HCC) is the fifth most common malignancy with an incidence of 250,000 diagnoses per year and approximately one million deaths annually worldwide. It is one of the most common human cancers, especially in East Asia and Sub-Saharan Africa where oncogenic hepatitis virus infections are prevalent (1-4). In Korea, it accounts for an estimated $12.2 \%$ of all malignancies, with an incidence of $16.4 \%$ and $6.5 \%$ in the male and female population, respectively (5). Hepatocarcinogenesis is considered to be a multi-factorial and multi-step process of genetic changes that cumulatively contribute to the development of a malignant tumor in the liver (6). Although the inactivation of several tumor suppressor genes, such as p53, retinoblastoma $(\mathrm{Rb})$ and $\mathrm{p} 16^{\mathrm{INK} 4 \mathrm{~A}}$, has been reported in HCCs (7-14), other genetic alterations in HCCs are not well understood.

The phosphatase and tensin homolog deleted from chromosome 10 (PTEN), also known as mutated in multiple advanced cancers 1 (MMAC1) or TGF- - -regulated and epithelial cell-enriched phosphatase (TEP1), is a novel tumor suppressor gene originally isolated from a chromosomal region (10q23) homozygously deleted in several cancer cell lines including glioma, breast and prostate cancers $(15,16)$. The PTEN gene contains nine exons and encodes a 403amino acid protein that dephosphorylates both lipids and proteins. The major lipid substrate of PTEN is phosphatidylinositol-3,4,5-triphosphate (PIP3), which is generated by the action of PIP3 kinases (PIP3ks). PIP3 has been shown to activate protein kinase $\mathrm{B}(\mathrm{PKB} / \mathrm{Akt})$, a serine-threonine kinase that is involved in cell proliferation and oncogenesis $(17,18)$.

PTEN is deleted and mutated in a variety of human tumors such as adult glioma (19), melanoma (20), prostate cancer $(21,22)$, endometrial cancer $(23-25)$, breast cancer $(26)$, and lung carcinoma (27). Loss of heterozygosity ( $\mathrm{LOH}$ ) has been reported in HCC on several chromosomal regions including 9p (p16 $\left.{ }^{\mathrm{INK} 4 \mathrm{~A}}\right), 13 \mathrm{q}(\mathrm{Rb})$, and 10q (PTEN) $(13,28,29)$. Although deletions and mutations in the $\mathrm{p} 16^{\mathrm{INK} 4 \mathrm{~A}}$ and $\mathrm{p} 53$ genes have 
Table I. Microsatellite markers on chromosome 10q23 for LOH analysis.

\begin{tabular}{|c|c|c|c|}
\hline Markers & Primers & Sequences (5' to $\left.3^{\prime}\right)$ & Location: \\
\hline \multirow[t]{2}{*}{ D10S579 } & AFM205xe3a & AAGCAAGTGAAGTCTTAGAACCAC & $10 q 23$ \\
\hline & AFM205xe3m & CCACAAGTAACAGAAAGCCTGTCTC & \\
\hline \multirow[t]{2}{*}{ D10S215 } & RHI068:a & AGAAAGACAGACAAAAAGATGAGG & $10 q 23$ \\
\hline & RH1068:b & GAGTTGCCAGTGTGCTTTAC & $(\mathrm{PTEN})$ \\
\hline \multirow[t]{2}{*}{ AFMa086wg9 } & AFMaO86wg9.a & AAATGTACGGTTCATTGACTT & $10 q 23$ \\
\hline & AFMaO86wg9.m & GACTGACTACAAATGGGCA & (PTEN) \\
\hline \multirow[t]{2}{*}{ D10S541 } & AFM205xe3a & AAGCAAGTGAAGTCTTAGAACCACC & $10 \mathrm{q} 23$ \\
\hline & AFM205xe3m & CCACAAGTAACAGAAAGCCTGTCTC & (PTEN) \\
\hline \multirow[t]{2}{*}{ AFM280we1 } & AFM280we1.a & GCTTATAGTTTGTAGATGTTCAGAG & $10 q 23$ \\
\hline & AFM280we1.m & GAGTGGATTATGGGTCTGTG & \\
\hline \multirow[t]{2}{*}{ WI-10275 } & WI-10275-1 & TTGCAGCACAATTTATTATCTGG & $10 \mathrm{q} 23$ \\
\hline & WI-10275-2 & TGTTGGGATCTGAGGTGATATG & \\
\hline \multirow[t]{2}{*}{ D10S2281 } & WI-6971-1 & ТTCТTАТТTТТСССССАССС & $10 \mathrm{q} 23$ \\
\hline & WI-6971-2 & ATAATTCCAAACACAAGGGGC & \\
\hline \multirow[t]{2}{*}{ D10S2177 } & AFM282ycla & CCGATCAATGAGGAGTGCC & $10 \mathrm{q} 23$ \\
\hline & AFM282yclm & ATACACCCAGCCAATGCTGC & \\
\hline
\end{tabular}

frequently been reported in HCCs (7-14), somatic mutations of the PTEN gene have been detected only in a minority of HCC cases (29-34).

In this study, we examined the genetic alterations in the PTEN gene in HCC tissues from Korean patients by carrying out an $\mathrm{LOH}$ analysis at the 10q23 chromosomal region and a sequencing analysis of the PTEN gene. Alterations of the PTEN gene and its correlation with the clinicopathological data of the HCC patients, are discussed.

\section{Materials and methods}

Tissues and DNA extraction. We used samples of 18 surgically resected HCCs and non-tumorous liver tissues from the corresponding patients. The tissues were snap frozen using liquid nitrogen and stored immediately at $-80^{\circ} \mathrm{C}$ until analysis. The genomic DNA from the microdissected tumor tissues and the corresponding normal tissues were prepared using a QIAamp Tissue Kit (Qiagen, Chatwirth, CA, USA).

LOH analysis. LOH was performed using 8 microsatellite markers spanning the 10q23 chromosomal region. The microsatellite markers used in this study are shown in Table I. The primers were purchased from Research Genetics (Huntsville, AL, USA). The polymerase chain reaction (PCR) was carried out in $10 \mu \mathrm{l}$ reaction volumes that contained $20 \mathrm{ng}$ genomic DNA, 1X PCR buffer (Gibco-BRL, Grand Island, NY, USA), $100 \mu \mathrm{M}$ each of dATP, dGTP and dTTP, $5 \mu \mathrm{M} \mathrm{dCTP}, 1 \mu \mathrm{Ci}$ $\left[\alpha^{-32} \mathrm{P}\right] \mathrm{dCTP}, 2.5 \mathrm{pmol}$ of each primer, and 1 unit Taq polymerase (Perkin-Elmer, Sunnyville, CA, USA). PCR was performed in a Thermocycler 9600 (Perkin-Elmer) under the following conditions: Initial denaturation at $94^{\circ} \mathrm{C}$ for $2 \mathrm{~min}$ followed by 30 cycles of amplification $\left(94^{\circ} \mathrm{C}\right.$ for $30 \mathrm{sec}$, $58^{\circ} \mathrm{C}$ for $30 \mathrm{sec}$, and $72^{\circ} \mathrm{C}$ for $30 \mathrm{sec}$ ), and a final extension at $72^{\circ} \mathrm{C}$ for $7 \mathrm{~min}$. The PCR product was separated on a denaturing polyacrylamide gel and autoradiography was used to detect the bands. $\mathrm{LOH}$ was scored when the intensity of one allele was absent or at least $70 \%$ reduced in the tumor alleles when compared to the corresponding wild-type alleles for the informative cases.

Single-strand conformational polymorphism (SSCP) analysis. SSCP analysis was performed on exons 1 through 9 of PTEN using intron-based primers as previously described (22). An aliquot of the PCR products was diluted with the same volume of denaturing loading buffer, heated to $95^{\circ} \mathrm{C}$ for $4 \mathrm{~min}$, and then promptly cooled on ice. Three microliters of each diluted sample were separated on a $0.25 X$ Mutation Enhancement Gel (FMC Bioproducts, Rockland, ME, USA) containing 5\% glycerol. Electrophoresis was carried out at $12 \mathrm{~W}$ for $15 \mathrm{~h}$ at room temperature. The gels were dried and exposed to Kodak XAR film at $-80^{\circ} \mathrm{C}$ for 1 to $3 \mathrm{~h}$.

Sequencing. The abnormal bands detected by the SSCP analysis were eluted from the gels and reamplified by PCR for 30 extra-cycles. The amplified DNA was separated on a $1 \%$ agarose gel followed by elution using a Gel Extraction Kit (Qiagen). The purified PCR products were sequenced by a dideoxy-chain termination cycle sequencing method using an ABI 377 Automated Sequencer (Applied Biosystems, Inc., Foster City, CA, USA). The primers used for the sequencing were the same as those used for the SSCP analysis. 
Table II. Clinicopathological data of the HCC patients.

\begin{tabular}{|c|c|c|c|c|c|c|c|c|}
\hline $\mathrm{Pt}$ & Sex/Age & $\begin{array}{l}\text { Cirrhosis } \\
\text { (etiology) }\end{array}$ & $\begin{array}{c}\mathrm{HBs} \\
\mathrm{Ag} / \mathrm{Ab}\end{array}$ & $\begin{array}{c}\mathrm{HCV} \\
\mathrm{Ab}\end{array}$ & $\begin{array}{c}\text { Mass } \\
\text { no. }\end{array}$ & Size $(\mathrm{cm})$ & $\begin{array}{c}\text { Differ- } \\
\text { entiation }\end{array}$ & $\begin{array}{l}\text { Tumor } \\
\text { grade }^{a}\end{array}$ \\
\hline 1 & $\mathrm{M} / 42$ & + & $+/-$ & - & Multi & $15 \times 12$ & $\mathrm{P}$ & III \\
\hline 2 & $\mathrm{M} / 52$ & + & $+/-$ & + & 1 & $7.6 \times 6$ & $\mathrm{P}$ & III \\
\hline 3 & $\mathrm{M} / 27$ & - & $+/-$ & - & 1 & $90 \times 70$ & $\mathrm{P}$ & III \\
\hline 4 & $\mathrm{M} / 60$ & + & $+/-$ & - & 1 & $10 \times 20$ & $\mathrm{P}$ & III \\
\hline 5 & $\mathrm{M} / 53$ & + & $+/-$ & - & 1 & $40 \times 2.2$ & $\mathrm{P}$ & III \\
\hline 6 & $\mathrm{~F} / 39$ & - & $-/+$ & - & 1 & $10 \times 50$ & W & I \\
\hline 7 & M/61 & - & $+/-$ & - & 1 & $4.7 \times 4.3$ & $\mathrm{P}$ & III \\
\hline 8 & $\mathrm{~F} / 72$ & + & $-/-$ & + & 1 & $10 \times 7$ & $\mathrm{P}$ & III \\
\hline 9 & $\mathrm{M} / 50$ & Fatty liver & $-/-$ & - & 1 & $4.3 \times 4$ & $\mathrm{P}$ & III \\
\hline 10 & $\mathrm{~F} / 49$ & - & $+/-$ & - & 1 & $10 \times 7$ & $\mathrm{P}$ & III \\
\hline 11 & $\mathrm{~F} / 43$ & - & $+/-$ & - & 3 & $7.6 \times 3$ & $\mathrm{P}$ & III \\
\hline 12 & $\mathrm{~F} / 46$ & + & $+/-$ & - & 1 & $5.6 \times 4$ & W & II \\
\hline 13 & $\mathrm{M} / 48$ & - & $+/+$ & - & 3 & $2 \times 3$ & W & II \\
\hline 14 & $\mathrm{M} / 58$ & + & $-/+$ & - & 1 & $9 \times 7$ & $\mathrm{P}$ & III \\
\hline 15 & $\mathrm{M} / 47$ & + & $-/-$ & + & 1 & $2 \times 2.2$ & $\mathrm{~W}$ & II \\
\hline 16 & $\mathrm{~F} / 44$ & - & $+/-$ & - & 3 & $7.5 \times 4.6$ & W & II \\
\hline 17 & $\mathrm{M} / 48$ & + & $+/-$ & - & 1 & $2 \times 1.4$ & W & II \\
\hline 18 & $\mathrm{M} / 47$ & + & $+/-$ & - & 1 & $4.2 \times 3.3$ & $\mathrm{P}$ & III \\
\hline
\end{tabular}

aTumor grade was according to Edmondson's Steiner classification. Pt, patient number; HBs, hepatitis B virus surface antigen; Ag, antigen; $\mathrm{Ab}$, antibody; $\mathrm{HCV}$, hepatitis $\mathrm{C}$ virus; $\mathrm{M}$, male; F, female; $\mathrm{P}$, poorly differentiated; $\mathrm{W}$, well differentiated; multi, more than 4 masses.

Table III. Chromosome 10q23 allelic abnormalities in Korean HCC patients.

\begin{tabular}{llll}
\hline Markers & LOH/IC $(\%)$ & AB/IC $(\%)$ & AM/IC (\%) \\
\hline D10S579 & $1 / 16(6.3)$ & $0 / 16(0)$ & $0 / 16(0)$ \\
D10S215 & $6 / 11(54.5)$ & $0 / 11(0)$ & $0 / 11(0)$ \\
AFMa086wg9 & $2 / 17(11.8)$ & $0 / 17(0)$ & $1 / 17(5.9)$ \\
D10S541 & $1 / 15(6.7)$ & $0 / 15(0)$ & $0 / 15(0)$ \\
AFM280we1 & $1 / 14(7.1)$ & $0 / 14(0)$ & $0 / 14(0)$ \\
WI-10275 & $0 / 16(0)$ & $0 / 16(0)$ & $1 / 16(6.3)$ \\
D10S2177 & $3 / 15(20)$ & $4 / 15(26.7)$ & $0 / 15(0)$ \\
D10S2281 & $1 / 15(6.7)$ & $0 / 15(0)$ & $1 / 15(6.7)$ \\
\hline
\end{tabular}

$\mathrm{AB}$, additional bands; AM, amplification; IC, informative cases.

\section{Results}

Characterization of patients. We obtained samples from 18 Korean patients (12 males, 6 females) who underwent partial hepatectomy for HCC. The patients ranged in age from 27-72 years, with a mean age of 49.5. The most frequent underlying liver disease was hepatitis B infection (15 patients). Three patients had a history of hepatitis $\mathrm{C}$ infection, and one of them (patient no. 2) showed a coinfection of hepatitis B and
C. Cirrhosis accompanied hepatitis B- or (and) C-positive infection in 10 out of the 17 cases with hepatitis infection. One patient (no. 9), with no history of hepatitis, had a fatty liver. Most patients (14 cases) had a single tumor mass. Three patients had three tumor masses and one patient over 10 masses. Six of the HCC tissues were well differentiated $(33.3 \%)$ and 12 of them were poorly differentiated (66.7\%). The clinicopathological data are summarized in Table II.

LOH at 10q23 region in HCC tissues. Thirteen out of the 18 (72\%) HCCs had at least 1 microsatellite abnormality at 8 microsatellite markers spanning chromosome 10q23. The PTEN region (10q23.3) corresponds to the markers, D10S215, AFMa086wg9, and D10S541. LOH was found at D10S215 in 6 of 11 informative cases (IC) $(54.5 \%)$, at AFMa086wg9 in 2 of 17 IC $(11.8 \%)$, and at D10S541 in 1 of 15 ICs $(6.7 \%)$. Eight of the 18 patients $(44.4 \%)$ showed LOH in the PTEN region, one of which (patient 15) had LOH at both D10S215 and D10S541. D10S2177 was the hot spot for allelic abnormalities showing both LOH (20\%, 3 of 15 IC) and microsatellite instability (26.7\%, 4 of 15 IC). Patient 15 showed microsatellite abnormalities in 6 of the 8 markers, including LOHs at D10S215, D10S541, and D10S2281 and amplifications at D10S579, AFMa086wg9, and WI-12075. Amplification was found only in patient 15 (Tables III and IV). A map of the 10q chromosomal region, sites of microsatellite markers, and representative photographs of the allelic abnormalities are shown in Fig. 1. 
Table IV. Summary of chromosome 10q23 microsatellite abnormalities and PTEN mutations in Korean HCC patients.

\begin{tabular}{|c|c|c|c|c|}
\hline \multirow[t]{2}{*}{$\mathrm{Pt}$} & \multirow[t]{2}{*}{ 10q23 microsatellite abnormalities } & \multicolumn{3}{|c|}{ PTEN mutation } \\
\hline & & Mutations (codon no.) & & Results \\
\hline 1 & AFMa086wg9a, D10S2177b & & ND & \\
\hline 2 & $\mathrm{D} 10 \mathrm{~S} 215^{\mathrm{a}}$ & $\begin{array}{c}\text { Exon } 6(188) ; \\
\text { CTG-Val to CTA }\end{array}$ & & $\begin{array}{l}\text { Silent } \\
\text { mutation }\end{array}$ \\
\hline 3 & No & & ND & \\
\hline 4 & $\mathrm{D} 10 \mathrm{~S} 2177^{\mathrm{b}}$ & & ND & \\
\hline 5 & No & & ND & \\
\hline 6 & No & & ND & \\
\hline 7 & No & & ND & \\
\hline 8 & No & & ND & \\
\hline 9 & AFMa086wg9a & & ND & \\
\hline 10 & $\mathrm{D} 10 \mathrm{~S} 2177^{\mathrm{b}}$ & $\begin{array}{l}\text { Intron } 5 ; \mathrm{T} \text { insertion at } \\
\text { 6th nucleotide }\end{array}$ & & $\begin{array}{l}\text { Splicing } \\
\text { variant }\end{array}$ \\
\hline 11 & $\mathrm{D} 10 \mathrm{~S} 215^{\mathrm{a}}$ & & ND & \\
\hline 12 & $\mathrm{D} 10 \mathrm{~S} 2177^{\mathrm{b}}$ & & ND & \\
\hline 13 & AFM280we $1^{a}$ & & ND & \\
\hline 14 & $\mathrm{D} 10 \mathrm{~S} 215^{\mathrm{a}}$ & & ND & \\
\hline 15 & 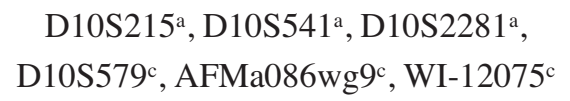 & & ND & \\
\hline 16 & $\mathrm{D} 10 \mathrm{~S} 215^{\mathrm{a}}, \mathrm{D} 10 \mathrm{~S} 2177^{\mathrm{a}}$ & & ND & \\
\hline 17 & $\mathrm{D} 10 \mathrm{~S} 2177^{\mathrm{a}}$ & & ND & \\
\hline 18 & $\mathrm{D} 10 \mathrm{~S} 215^{\mathrm{a}}, \mathrm{D} 10 \mathrm{~S} 2177^{\mathrm{a}}$ & & ND & \\
\hline
\end{tabular}

${ }^{a} \mathrm{LOH}$, badditional bands, and ${ }^{c}$ amplification of tumor tissue. Pt, patient number; ND, not determined. Exons with abnormal PCR-SSCP patterns were sequenced.

A

\section{Chromosome 10}

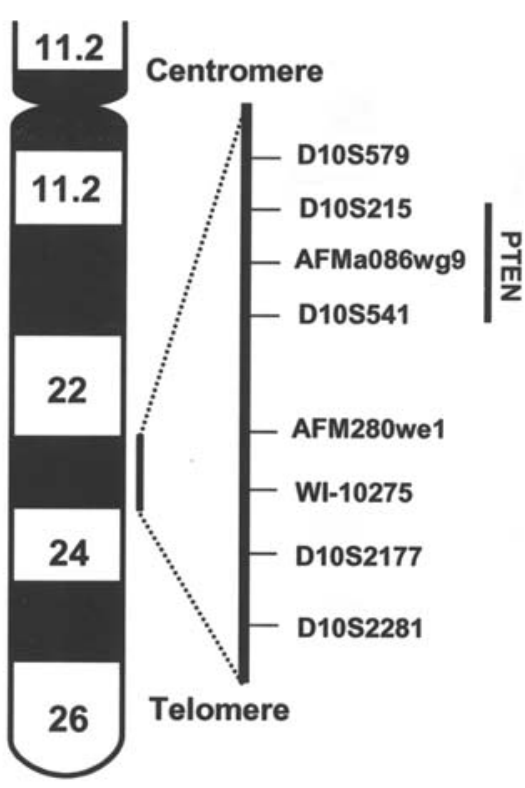

B

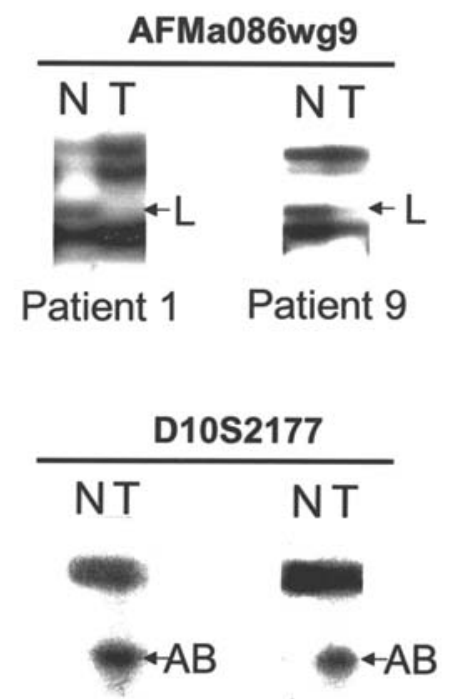

Patient 1 Patient 4

Figure 1. Map of chromosome 10q (A) and the representative photographs of microsatellite abnormalities (B). Microsatellite markers, PTEN region, and map positions are illustrated. N, normal tissue; T, tumor tissue; L, LOH; AB, additional bands. 
A

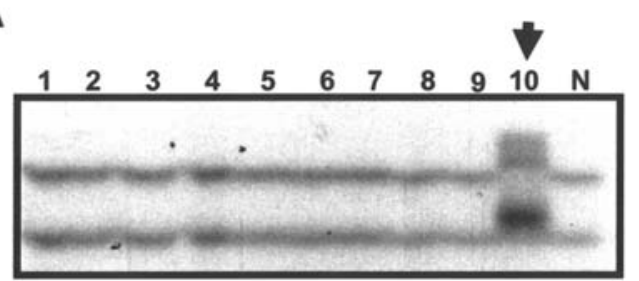

Exon 5

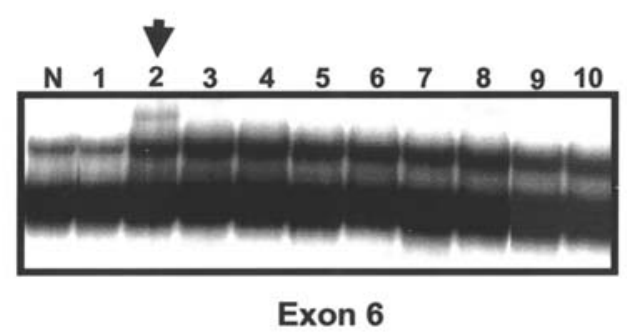

B

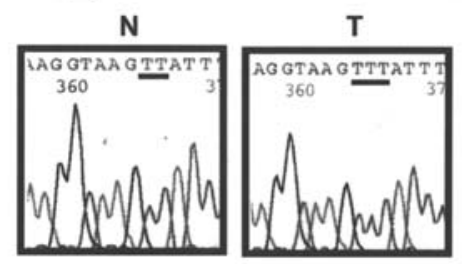

Patient 10

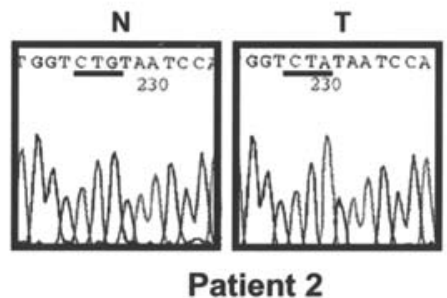

Figure 2. SSCP and sequencing analyses of the PTEN gene in Korean HCC patients. (A) Representative SSCP patterns. (B) PTEN mutations. A single base (T) insertion was found at five bases downstream from the end of exon 5 in patient 10. A silent mutation (CTG-Val to CTA) was detected in exon 6 of patient 2. The arrows indicate lanes with abnormally migrating bands. $\mathrm{N}$, normal tissue; $\mathrm{T}$, tumor tissue.

SSCP and sequencing analysis of PTEN gene. SSCP mobility shift was found in 2 cases; in exon 5 of patient 10 and exon 6 of patient 2 (Fig. 2A). Patient 10 had a single base (T) insertion in intron 5 ( 5 bases downstream from the end of exon 5), while patient 2 had a silent mutation in exon 6 (codon 188, CTG-Val to CTA) (Fig. 2B). Microsatellite abnormalities and PTEN mutation data are summarized in Table IV.

\section{Discussion}

Since PTEN dephosphorylates PIP3, functionally antagonizing phosphoinositide 3-kinase (PI3K) and its downstream Akt/PKB pathway that mediates cell proliferation, growth, and apoptosis, the inactivation of PTEN can lead to the tumorous growth of cells $(17,18)$. PTEN is frequently abrogated in human malignant tumors including glioma, melanomas, endometrial cancers, prostate cancers, and breast carcinomas (19-26). However, the role of the PTEN gene in $\mathrm{HCC}$ is not yet clearly understood.

We tested 18 Korean HCCs for allelic abnormalities with 8 microsatellite markers that flank chromosome 10q23 (Fig. 1) (Tables III and IV). LOH was detected in 10 of the $18(55.6 \%)$ HCCs, eight of which (44.4\%) were at the PTEN region (D10S215, AFMa086wg9, and D10S541). Microsatellite abnormalities were frequently found at D10S2177, showing both LOH (3 of $15 \mathrm{IC}, 20 \%$ ) and additional bands (4 of 15 IC, 26.7\%). Since D10S2177 is located on the telomere side of the PTEN region of chromosome 10q23, this result suggests that multiple genetic changes, including gene(s) in (or near) the D10S2177 locus as well as in PTEN, occur during the carcinogenesis of Korean HCC patients. For example, patient 15 showed microsatellite abnormalities in 6 of 8 the markers, including LOHs at D10S215, D10S541, and D10S2281 and amplifications at D10S579, AFMa086wg9, and WI-12075.
Of interest, in the Korean HCC patients tested, patient 9 who had a fatty liver with no history of viral hepatitis or cirrhosis showed LOH in the PTEN region (AFMa086wg9). This result therefore suggests that genetic alteration(s), including PTEN inactivation, can induce the development of a fatty liver followed by HCC in the absence of oncogenic viral hepatitis. Recently, several reports have demonstrated that hepatocyte-specific PTEN deletion causes fatty liver and HCC in mouse models $(35,36)$. According to these studies, the absence of PTEN, a negative regulator of PI3K and its downstream target Akt, resulted in the activation of Akt in liver-specific PTEN-deficient mice. Activated Akt then induced peroxisome proliferator-activated receptor-gamma $($ PPAR- $\gamma$ ), a key transcriptional activator for adipogenesis and lipogenesis. Activated Akt also led to hepatocyte hyperproliferation and increased production of the reactive oxygen species, both of which could contribute to hepatocarcinogenesis. Thus, the development of HCC in patient 9, who had a fatty liver and LOH in the PTEN region, could be explained by this hypothesis.

The majority of the somatic PTEN mutations have been reported to be nonsense, frameshift, or splicing mutations resulting in the truncation of the protein (37). We found PTEN mutations in 2 of the 18 HCC patients: A single base (T) insertion in intron 5 (patient 10) and a silent mutation (CTG-Val to CTA) at codon 188 in exon 6 (patient 2). Since the insertion in intron 5 was at the end of the 5'-end splice signal (AG-GUAAGUU), this mutation could result in the inactivation of PTEN via aberrant RNA splicing. Mutations in intron 5 have been reported in glioblastoma (AG-GTAAG to AG-GTAA) (38) and in endometrial cancers (AG-GTAAG to AG-GAAG) (39) in the 5'-splicing sequence. Although PTEN can be inactivated in HCC by other mechanisms, for example, by transcriptional silencing by promoter methylation, mutations of non-coding regulatory sequences, or increased 
protein degradation, PTEN mutations in HCC are a rare phenomenon. The mutation frequency of the PTEN gene was 0 to $11.8 \%$ in HCCs of Taiwanese, Chinese, or Japanese populations (28-34). In line of this, our results showing PTEN mutations in 2 of the $18(11.1 \%)$ HCCs from a Korean population were consistent with these previous findings.

The fact that PTEN mutations were rare in HCCs with extensive microsatellite abnormalities suggests that the loss of one PTEN allele could be sufficient to provide the tumorous growth of hepatocytes. The classical knowledge of tumor suppressor genes has been that both copies must be lost for tumorigenesis to occur. However, one particular study has suggested that only a partial loss of PTEN could be enough to promote tumor development (40). A study on PTEN heterozygous mice has shown an increased survival and proliferation of several cell types (41). In agreement with these findings, the presence of an intact copy of PTEN and a partial loss of protein expression are shown to be very common in many tumor types (42). According to this report, in some of these tumors, particularly in breast and lung cancers, even though the PTEN mutation was rare (3 to $4 \%$ ), LOH at the PTEN locus was very common $(31 \%$ and $47 \%$ of tumors, respectively). This finding was consistent with our result in Korean HCC patients (11.1\% mutation and $44.4 \% \mathrm{LOH})$.

In this study, we have shown the microsatellite abnormalities of chromosome 10q23 and mutations of the PTEN gene in Korean HCC patients. Our data suggest that genetic alterations of chromosome 10q23 including the PTEN gene could be important in hepatocarcinogenesis in the Korean population.

\section{Acknowledgements}

This research was supported by grant of Yeungnam University Medical Center (2000).

\section{References}

1. Cameron RG: Identification of the putative first cellular step of chemical hepatocarcinogenesis. Cancer Lett 47: 163-167, 1989.

2. Miyazaki M and Namba M: Atlas of human tumor cell lines. In: Hepatocellular carcinomas. Hay RJ, Park J-G and Gazdar A (eds). Academic Press Inc., San Diego, pp185-212, 1994.

3. Tang ZY: Hepatocellular carcinoma. J Gastroenterol Hepatol 15 (Suppl): G1-G7, 2000.

4. Wang YE, Wang HY and Wu MC: Identification and characterization of a novel human hepatocellular carcinomaassociated gene. Br J Cancer 85: 1162-1167, 2001.

5. Suh CI, Suh KA, Park SH, Chang HJ, Ko JW and Ahn DH: Annual report of the central cancer registry in Korea-1998. J Korean Cancer Assoc 32: 827-834, 2000.

6. Dragon YP, Sargent L, Xu Y-D, Xu Y-H and Pitot HC: The initiation-promotion-progression model of rat hepatocarcinogenesis. Proc Soc Exp Biol Med 202: 16-24, 1993.

7. Biden K, Young J, Buttenshaw R, Searle J, Cooksley G, Xu DB and Leggett B: Frequency of mutation and deletion of the tumor suppressor gene CDKN2A (MTS1/p16) in hepatocellular carcinoma from an Australian population. Hepatology 25: 593-597, 1997.

8. Bressac B, Kew M, Wand J and Ozturk M: Selective G to T mutations of p53 gene in hepatocellular carcinoma from southern Africa. Nature 350: 429-431, 1991.

9. Hui AM, Sakamoto M, Kanai Y, Ino Y, Gotoh M, Yokota J and Hirohashi S: Inactivation of p16INK4 in hepatocellular carcinoma. Hepatology 24: 575-579, 1996.

10. Kaino M: Alterations in the tumor suppressor genes p53, RB, p16/MTS1, and p15/MTS2 in human pancreatic cancer and hepatoma cell lines. J Gastroenterol 32: 40-46, 1997.
11. Kang MS, Lee HJ, Lee JH, Ku JL, Lee KP, Kelley MJ, Won YJ, Kim ST and Park JG: Mutation of p53 gene in hepatocellular carcinoma cell lines with HBX DNA. Int J Cancer 67: 898-902, 1996.

12. Kita R, Nishida N, Fukuda Y, Azechi H, Matsuoka Y, Komeda T, Sando T, Nakao K and Ishizaki K: Infrequent alterations of the p16 ${ }^{\mathrm{INK} 4 \mathrm{~A}}$ gene in liver cancer. Int J Cancer 67: 176-180, 1996.

13. Lee TJ, Bae JJ, Lee JS, Lee SY, Kim HJ, Kim SK, Lee JY and Lee TY: p16-Rb abrogation of the pathway in Korean hepatocellular carcinomas. J Hepatogastroenterol 47: 1663-1668, 2000.

14. Liew CT, Li HM, Lo KW, Leow CK, Chan JY, Hin LY, Lau WY, Lai PB, Lim BK, Huang J, Leung WT, Wu S and Lee JC: High frequency of p16INK4A gene alterations in hepatocellular carcinoma. Oncogene 18: 789-795, 1999.

15. Li J, Yen C, Liaw D, Podsypanina K, Bose S, Wang SI, Puc J, Miliaresis C, Rodgers L, McCombie R, Bigner SH, Giovanella BC, Ittmann M, Tycko B, Hibshoosh H, Wigler MH and Parsons R: PTEN, a putative protein tyrosine phosphatase gene mutated in human brain, breast, and prostate cancer. Science 275: 1943-1947, 1997.

16. Steck PA, Pershouse MA, Jasser SA, Yung WK, Lin H, Ligon AH, Langford LA, Baumgard ML, Hattier T, Davis T, Frye C, Hu R, Swedlund B, Teng DH and Tavtigian SV: Identification of a candidate tumour suppressor gene, MMAC1, at chromosome $10 q 23.3$ that is mutated in multiple advanced cancers. Nat Genet 15: 356-362, 1997.

17. Maehama T and Dixon JE: The tumor suppressor, PTEN/MMAC1, dephosphorylates the lipid second messenger, phosphatidylinositol 3,4,5-trisphosphate. J Biol Chem 273: 13375-13378, 1998.

18. Wu X, Senechal K, Neshat MS, Whang YE and Sawyers CL: The PTEN/MMAC1 tumor suppressor phosphatase functions as a negative regulator of the phosphoinositide 3-kinase/Akt pathway. Proc Natl Acad Sci USA 95: 15587-15591, 1998.

19. Rasheed BK, Stenzel TT, McLendon RE, Parsons R, Friedman AH, Friedman HS, Bigner DD and Bigner SH: PTEN gene mutations are seen in high-grade but not in low-grade gliomas. Cancer Res 57: 4187-4190, 1997.

20. Guldberg P, thor Straten P, Birck A, Ahrenkiel V, Kirkin AF and Zeuthen J: Disruption of the MMAC1/PTEN gene by deletion or mutation is a frequent event in malignant melanoma. Cancer Res 57: 3660-3663, 1997.

21. Gray IC, Phillips SM, Lee SJ, Neoptolemos JP, Weissenbach J and Spurr NK: Loss of the chromosomal region 10q23-25 in prostate cancer. Cancer Res 55: 4800-4803, 1995

22. Suzuki H, Freije D, Nusskern DR, Okami K, Cairns P, Sidransky D, Isaacs WB and Bova GS: Interfocal heterogeneity of PTEN/MMAC1 gene alterations in multiple metastatic prostate cancer tissues. Cancer Res 58: 204-209, 1998.

23. Kong D, Suzuki A, Zou TT, Sakurada A, Kemp LW, Wakatsuki S, Yokoyama T, Yamakawa H, Furukawa T, Sato M, Ohuchi N, Sato S, Yin J, Wang S, Abraham JM, Souza RF, Smolinski KN, Meltzer SJ and Horii A: PTEN1 is frequently mutated in primary endometrial carcinomas. Nat Genet 17:143-144, 1997.

24. Risinger JI, Hayes K, Berchuck A and Barrett JC: PTEN/MMAC1 Mutations in endometrial cancers. Cancer Res 57: 4736-4738, 1997.

25. Tashiro H, Blazes MS, Wu R, Cho KR, Bose S, Wang SI, Li J, Parsons R and Ellenson LH: Mutations in PTEN are frequent in endometrial carcinoma but rare in other common gynecological malignancies. Cancer Res 57: 3935-3940, 1997

26. Rhei E, Kang L, Bogomolniy F, Federici MG, Borgen PI and Boyd J: Mutation analysis of the putative tumor suppressor gene PTEN/MMAC1 in primary breast carcinomas. Cancer Res 57: 3657-3659, 1997.

27. Zhang L, Liu T, Liu H, Gao J and Gu C: Loss and inactivation of PTEN/MMAC1/TEP1 gene in lung cancer. Zhonghua Bing Li Xue Za Zhi 29: 85-88, 2000.

28. Piao Z, Park C, Park JH and Kim H: Allelotype analysis of hepatocellular carcinoma. Int J Cancer 75: 29-33, 1998.

29. Fujiwara Y, Hoon DS, Yamada T, Umeshita K, Gotoh M, Sakon M, Nishisho I and Monden M: PTEN/MMAC1 mutation and frequent loss of heterozygosity identified in chromosome $10 \mathrm{q}$ in a subset of hepatocellular carcinomas. Jpn J Cancer Res 91: 287-292, 2000.

30. Guo SP, Wang L, Wang WL, Li QL, Wang WY and Zhang J: Mutations of tumor suppressor gene PTEN mutations in hepatocellular carcinoma and its implications in tumor proliferation and apoptosis. Zhonghua Bing Li Xue Za Zhi 35: 467-472, 2006. 
31. Kawamura N, Nagai H, Bando K, Koyama M, Matsumoto S, Tajiri T, Onda M, Fujimoto J, Ueki T, Konishi N, Shiba T and Emi M: PTEN/MMAC1 mutations in hepatocellular carcinomas: somatic inactivation of both alleles in tumors. Jpn J Cancer Res 90: 413-418, 1999.

32. Yao YJ, Ping XL, Zhang H, Chen FF, Lee PK, Ahsan H, Chen CJ, Lee PH, Peacocke M, Santella RM and Tsou HC: PTEN/ MMAC1 mutations in hepatocellular carcinomas. Oncogene 18: 3181-3185, 1999.

33. Yeh KT, Chang JG, Chen YJ, Chen ST, Yu SY, Shih MC, Perng LI, Wang JC, Tsai M and Chang CP: Mutation analysis of the putative tumor suppressor gene PTEN/MMAC1 in hepatocellular carcinoma. Cancer Invest 18: 123-129, 2000.

34. Zhang LN, Zha XL, Yu Q and He JY: Mutation analysis of the tumor suppressor gene PTEN/MMAC1/TEP1 in human hepatocellular carcinoma. Shi Yan Sheng Wu Xue Bao 33: 223-227, 2000.

35. Horie Y, Suzuki A, Kataoka E, Sasaki T, Hamada K, Sasaki J, Mizuno K, Hasegawa G, Kishimoto H, Iizuka M, Naito M, Enomoto K, Watanabe S, Mak TW and Nakano T: Hepatocytespecific Pten deficiency results in steatohepatitis and hepatocellular carcinomas. J Clin Invest 113: 1774-1783, 2004.

36. Stiles B, Wang Y, Stahl A, Bassilian S, Lee WP, Kim YJ, Sherwin R, Devaskar S, Lesche R, Magnuson MA and Wu H: Liver-specific deletion of negative regulator Pten results in fatty liver and insulin hypersensitivity. Proc Natl Acad Sci USA 101: 2082-2087, 2004.
37. Bonneau D and Longy M: Mutations of the human PTEN gene Hum Mutat 16: 109-122, 2000

38. Fan X, Aalto Y, Sanko SG, Knuutila S, Klatzmann D and Castresana JS: Genetic profile, PTEN mutation and therapeutic role of PTEN in glioblastomas. Int J Oncol 21: 1141-1150, 2002.

39. Simpkins SB, Peiffer-Schneider S, Mutch DG, Gersell D and Goodfellow PJ: PTEN mutations in endometrial cancers with 10q LOH: additional evidence for the involvement of multiple tumor suppressors. Gynecol Oncol 71: 391-395, 1998.

40. Cook WD and McCaw BJ: Accommodating haploinsufficient tumor suppressor genes in Knudson's model. Oncogene 19: 3434-3438, 2000 .

41. Podsypanina K, Ellenson LH, Nemes A, Gu J, Tamura M, Yamada KM, Cordon-Cardo C, Catoretti G, Fisher PE and Parsons R: Mutation of Pten/Mmac1 in mice causes neoplasia in multiple organ systems. Proc Natl Acad Sci USA 96: 1563-1568, 1999.

42. Leslie NR and Downes CP: PTEN function: how normal cells control it and tumour cells lose it. Biochem J 382: 1-11, 2004. 